\title{
The potency of endophytic bacteria isolated from Ficus septica as phytoremediation promoting agent of $\mathrm{Cr}$ (VI) contaminated soil
}

\author{
NITA SHILFIANI ROHMAH, SUHARJONO, YOGA DWI JATMIKO, DIAN SISWANTO, IRFAN MUSTAFA \\ Department of Biology, Faculty of Mathematics and Natural Sciences, Universitas Brawijaya. J1. Veteran, Malang 65145, East Java, Indonesia. \\ Tel./fax.: +62-341-551611, `email: irfan@ub.ac.id
}

Manuscript received: 29 December 2019. Revision accepted: 11 April 2020.

\begin{abstract}
Rohmah NS, Suharjono, Jatmiko YD, Siswanto D, Mustafa I. 2020. The potency of endophytic bacteria isolated from Ficus septica as phytoremediation promoting agent of $\mathrm{Cr}(\mathrm{VI})$ contaminated soil. Biodiversitas 21: 1920-1927. Endophytic bacteria tolerant of chromium have the potential to reduce $\mathrm{Cr}$ (VI) to $\mathrm{Cr}$ (III) and produce compounds that can improve plant survival in Cr (VI) contaminated soils. This study was performed to isolate and identify $\mathrm{Cr}$ (VI)-tolerant bacteria from the endosphere of Ficus septica Burm.F growing on the tannery waste contaminated soil, Screening of bacteria was carried out based on the level of Cr (VI) tolerance. High tolerant isolates were tested for their potential of Indole Acetic Acid (IAA) and exopolysaccharide (EPS) production, phosphate solubilizing, and the presence of chromate reductase $(C h R)$ genes. The most potential bacterial isolate was identified based on $16 \mathrm{~S}$ rDNA sequences. The results showed that three isolates (E3, E4, and E8) were tolerant of Cr (VI) up to $900 \mathrm{mg} / \mathrm{L}$. E8 isolates produced the highest IAA production $(20.05 \mu \mathrm{g} / \mathrm{mL})$, phosphate solubilization $(127.78 \mu \mathrm{g} / \mathrm{mL})$, and EPS production $(9,70 \mu \mathrm{g} / \mathrm{mL})$, and all isolates had the ChR gene. E8 isolate was found to be $100 \%$ identical to Enterobacter cloacae ATCC 13047.
\end{abstract}

Keywords: Endophytic bacteria, Ficus septica Burm.F, Phytoremediation, Cr (VI), Enterobacter cloacae ATCC 13047

\section{INTRODUCTION}

Chromium (Cr) (VI) is one of the toxic heavy metals that contaminate the soil. Chromium (CrVI) is mutagenic, carcinogenic, and teratogenic in humans and other organisms (Schiavon et al. 2008). Cr (VI) mostly produced from leather tanning, welding, and paper production activities in the forms of the anion chromate $\left(\mathrm{CrO}_{4}{ }^{2-}\right)$ (Singh et al. 1998). Chromate has structural resembles with tetrahedral sulfate ion $\left(\mathrm{SO}_{4}{ }^{2-}\right)$. It can easily pass through cell membranes of microorganisms via $\mathrm{SO}_{4}{ }^{2-}$ transport pathway. The less toxic chromium in nature is $\mathrm{Cr}$ (III) (Cervantes et al. 2001; Krishna and Philip 2005).

Heavy metals can be detoxified by adsorption/ accumulation or conventional physicochemical treatments, but they are quite expensive and cumbersome. Therefore, safe and effective technology for detoxification of $\mathrm{Cr}(\mathrm{VI})$ contamination is needed, including by using microorganisms (Malik 2004). Some species of bacteria are tolerant of $\mathrm{Cr}(\mathrm{VI})$ and can accumulate and reduce it to $\mathrm{Cr}$ (III). Mechanisms of detoxifying $\mathrm{Cr}$ (VI) are periplasmic biosorption, intracellular, and extracellular bioaccumulation and biotransformation to less toxic metal oxidation states (Cervantes et al. 1990; Camargo et al. 2003).

$\mathrm{Cr}$ (VI) concentrations that are too high in the environment can not be accumulated but will be removed from the cells so as not to interfere with metabolism. The ability to accumulate $\mathrm{Cr}$ (VI) by bacteria can be enhanced when bacteria are associated with plants (Hynninen and Virta, 2009; Laghlimi et al. 2015). The genus Ficus can be used as phytoremediation agents for heavy metal polluted habitats. Ficus has a wide tolerance for various contaminants, and it has less frequent of biomass removal than herbaceous plants with many adventive roots that allow to penetrate widely into the substrate and increase the efficiency of the phytoremediation process (Yeo and Tan 2011; Luo et al. 2018).

Bacteria as phytoremediation promoting agents produce IAA, solubilize phosphate, and produce EPS. These abilities can improve plant metabolic functions and cell membrane permeability as well as increase plant resistance and its ability to remediate Cr (VI) (Davies et al. 2001; Srivastava et al. 2006; Lugtenberg and Kamilova 2009). Bacteria have the chromate reductase $(C h R)$ gene that catalyzes the reduction of $\mathrm{Cr}(\mathrm{VI})$ to $\mathrm{Cr}(\mathrm{III})$ Patra et al. 2010). Agrobacterium rhizogenes can accumulate and reduce heavy metal $\mathrm{Cr}(\mathrm{VI})$ and promote plant growth (Rosariastuti et al. 2013). Khan et al. (2015) reported that Bacillus, Pseudomonas, Enterobacter, Staphylococcus, Microbacterium, Arthrobacter isolated from Prosopis juliflora produce supporting compounds for $\mathrm{Cr}$ (VI) phytoremediation.

Many studies on the ability of bacteria to improve phytoremediation have been carried out. However, there are no studies on endophytic bacteria from Ficus septica Burm.F that are tolerant of $\mathrm{Cr}$ (VI). This study aimed to evaluate the potency of endophytic bacteria from Ficus septica Burm.F as phytoremediation promoting agent of $\mathrm{Cr}$ (VI) contaminated soil by evaluating IAA production, EPS production, and phosphate solubilization. The association of bacteria and plants has the potential to promote plant growth in $\mathrm{Cr}$ (VI) contaminated soil and improve the efficiency of $\mathrm{Cr}$ (VI) phytoremediation. 


\section{MATERIALS AND METHODS}

\section{Description of the sampling area}

Leaves of Ficus septica Burm.F was collected from the tannery waste disposal area in Malang City, East Java Province, Indonesia. The leaves were collected from three $F$. septica trees that grew in sediments around the tannery wastewater. The leaves were transferred into sterile plastic and stored in a coolbox.

\section{Isolation and screening of $\mathrm{Cr}$ (VI) tolerant endophytic bacteria}

The leaves of Ficus septica Burm.F were washed with sterile aqua dest and surface sterilized using $70 \%$ ethanol and $5.25 \%$ sodium hypochlorite, then rinsed with sterile aqua dest. Subsequently, 25g of surface-sterilized leaves were homogenized with a pestle and mortar in $225 \mathrm{~mL}$ $\mathrm{NaCl}(0.85 \%, w / v)$. Serial dilutions were carried out $10^{-7}$. $0.1 \mathrm{ml}$ of each suspension of dilution series was inoculated on Nutrient Agar (NA) medium containing $150 \mathrm{mg} / \mathrm{L} \mathrm{Cr}$ (VI). The medium was incubated at $28^{\circ} \mathrm{C}$ for 24 hours. Colonies with different morphologies that grow on the NA medium were picked out and purified by re-streaking onto the NA medium (Harley and Prescot 2002; Khan et al. 2015). Pure bacteria isolates were grown on NA medium containing $\mathrm{Cr}$ (VI) with multilevel concentrations from 150 $\mathrm{mg} / \mathrm{L}$ to $1000 \mathrm{mg} / \mathrm{L}$ by streaking plate method. All the plates were incubated at $28^{\circ} \mathrm{C}$ for two days, and the appearance of bacterial growth was observed (Khan et al. 2015).

\section{Determination of IAA production by endophytic bacteria Qualitative IAA production}

Qualitative and quantitative methods used to determine IAA production. Qualitative methods are carried out based on the modified method of Brick et al. (1991) using Salkowski's reagent. Salkowski's reagent is a mixture of $1.05 \mathrm{~g}$ ferric chloride $\left(\mathrm{FeCl}_{3}\right)$ and $60 \mathrm{~mL}$ sulfuric acid $\left(\mathrm{H}_{2} \mathrm{SO}_{4}\right)$. The reagent was cooled down and stored in a brown bottle with proper labelling (Gordon and Weber 1951). One ose of bacterial culture was inoculated on 25 mL Tryptic Soy Broth (TSB) medium containing 2\% Ltryptophan and $\mathrm{Cr}$ (VI) $150 \mathrm{mg} / \mathrm{L}$. The culture was incubated at $28^{\circ} \mathrm{C}$ for 24 hours. Bacterial cultures with a density of $10^{7}-10^{8}$ or optical density (OD) 0.5 were inoculated by spreading it on Tryptic Soy Agar (TSA) medium containing 2\% L-tryptophan and $\mathrm{Cr}$ (VI) 150 $\mathrm{mg} / \mathrm{L}$. After inoculation, $0.45 \mu \mathrm{m}$ nitrocellulose membranes placed onto agar plates and incubated at $28^{\circ} \mathrm{C}$ for 48 hours. The membrane was then flooded with Salkowski's reagent and incubated at room temperature in the dark for $30 \mathrm{~min}$ and observed for pink color development as an indication of IAA production.

\section{Quantitative IAA production}

The bacteria isolates that able to produce IAA in the qualitative assay were quantitatively analyzed with three replicates. One ose of bacterial culture was inoculated on $50 \mathrm{~mL}$ Tryptic Soy Broth (TSB) medium containing 2\% Ltryptophan and $\mathrm{Cr}$ (VI) $150 \mathrm{mg} / \mathrm{L}$. The culture was incubated at $28^{\circ} \mathrm{C}$ for 24 hours. After incubation, five milliliters of cultures (from the previous culture) were inoculated on $50 \mathrm{~mL}$ Tryptic Soy Broth (TSB) medium containing 2\% L-tryptophan and $\mathrm{Cr}$ (VI) $150 \mathrm{mg} / \mathrm{L}$ and incubated at $28^{\circ} \mathrm{C}$ for 96 hours. Three milliliters of bacterial suspension was taken out every 24 hours and centrifuged at $10000 \mathrm{rpm}$ for 10 minutes. Two milliliters of Salkowski's reagent was added into $1 \mathrm{~mL}$ of the supernatant and incubated for 30 minutes in a dark room. Pink color development indicated IAA production. The absorbance of the sample is measured at $535 \mathrm{~nm}$ using a UV-VIS spectrophotometer (UV Mini 1240). IAA concentrations were calculated based on IAA standard curves.

\section{Determination of phosphate solubilizing by endophytic bacteria Qualitative phosphate solubilization}

One ose of bacterial culture was inoculated on Pikovskaya Broth media added $0.5 \%$ Tricalcium phosphate (TCP) and Cr (VI) $150 \mathrm{mg} / \mathrm{L}$. The culture was incubated at $28^{\circ} \mathrm{C}$ for 24 hours. Sterile paper disks were inoculated with a $20 \mu \mathrm{L}$ bacterial culture at a density of $10^{7}-10^{8}$ or OD 0.5 and then placed on the Pikovskaya agar medium. The medium was incubated at $30^{\circ} \mathrm{C}$ for 72 hours. Comparative solubilization index measurement was carried out on day three of incubation by measuring halo zone and colony diameters. Phosphate solubilization index was determined by using the following formula: the ratio of the total diameter (colony + halo zone) and the diameter of the colony (Premono et al. 1996).

\section{Quantitative phosphate solubilization}

One ose of bacterial culture was inoculated on Pikovskaya Broth media added $0.5 \%$ Tricalcium phosphate (TCP) and Cr (VI) $150 \mathrm{mg} / \mathrm{L}$. Each isolate was determined with three replicates. The culture was incubated at $28^{\circ} \mathrm{C}$ for 24 hours. After incubation, five milliliters of bacterial culture with a density of $10^{7}-10^{8}$ or OD 0.5 were grown on Pikovskaya Broth media added with $0.5 \%$ Tricalcium phosphate (TCP) and $\mathrm{Cr}$ (VI) $150 \mathrm{mg} / \mathrm{L}$ and incubated at $28^{\circ} \mathrm{C}$ for 120 hours. Two milliliters of bacterial suspension were harvested every 24 hours and centrifuged at 10000 rpm for 10 minutes. And then, ten milliliters of chloromolybdate reagent and $0.1 \mathrm{~mL}$ of chlorostannous acid was added to $1 \mathrm{~mL}$ of the supernatant. The suspension was diluted to $25 \mathrm{~mL}$ using sterile aqua dest, homogenized, and incubated for 10 minutes. The absorbance of the sample was measured at $690 \mathrm{~nm}$ using a UV-VIS spectrophotometer (UV Mini 1240). Solubilized phosphate concentration is calculated based on a standard phosphate curve (Tirry et al. 2018).

\section{Determination of EPS production by endophytic bacteria Qualitative EPS production}

Bacteria were inoculated in two types of Nutrient Agar (NA) medium containing: (1) $2 \%(\mathrm{w} / \mathrm{v})$ sucrose and $\mathrm{Cr}$ (VI) $150 \mathrm{mg} / \mathrm{L}$ and (2) $2 \%$ (w/v) glucose and $\mathrm{Cr}$ (VI) 150 $\mathrm{mg} / \mathrm{L}$. The culture was incubated at $30^{\circ} \mathrm{C}$ for 48 hours. Colonies of bacteria that form thick mucous and slimy indicate that bacteria capable of producing EPS (Tallgren et al. 1999). Pawar et al. (2013) reported that NB medium contains 
sucrose and glucose as carbon sources at the same concentration indicated that NB media with sucrose as carbon source produced more EPS. It shows that sucrose metabolism is easier than glucose in bacteria isolates, therefore EPS quantitative tests used sucrose as the carbon source

\section{Quantitative EPS Production}

Exopolysaccharide (EPS) production quantified according to the modified method of Rida et al. (2015). One ose of the bacterial isolate was inoculated into Nutrient Broth (NB) medium containing 2\% (w/v) sucrose and $\mathrm{Cr}$ (VI) $150 \mathrm{mg} / \mathrm{L}$, then incubated at $30^{\circ} \mathrm{C}$ for 24 hours. Each isolate was determined in three replicates. Then, five milliliters of bacterial isolate with a density $10^{7}-10^{8}$ or OD 0.5 was taken out and grown on NB medium containing $150 \mathrm{mg} / \mathrm{L} \mathrm{Cr}(\mathrm{VI})$ and enriched with sucrose $2 \%(\mathrm{w} / \mathrm{v})$, then incubated at $30^{\circ} \mathrm{C}$ for 48 hours. A total of $10 \mathrm{~mL}$ of samples were centrifuged at $10000 \mathrm{rpm}$ at $4^{\circ} \mathrm{C}$ for 30 minutes. The supernatants were boiled at $100^{\circ} \mathrm{C}$ for 15 minutes. After cooling down, the supernatant was added with trichloroacetic acid $(4 \% \mathrm{w} / \mathrm{v})$ to precipitate protein and centrifuged at $10000 \mathrm{rpm}$ at $4^{\circ} \mathrm{C}$ for 30 minutes. The supernatants were precipitated overnight at $4^{\circ} \mathrm{C}$ in $20 \mathrm{~mL}$ ethanol for EPS precipitation. The suspension was centrifuged at $10000 \mathrm{rpm}$ at $4^{\circ} \mathrm{C}$ for 30 minutes, the pellets obtained were dried at $100^{\circ} \mathrm{C}$ for 15 minutes and the EPS weight was calculated (Cerantola et al. 2000).

\section{Data analysis}

Qualitative data were analyzed by descriptive method, while quantitative data were analyzed by two-way ANOVA using the univariate model to evaluate interactions between treatments at a $95 \%$ confidence level and followed by Tukey test to assess differences in the ability of each endophytic bacterial isolate using SPSS 16.0 software program for Windows.

\section{Detection of chromate reductase $(C h R)$ gene}

Bacterial DNA chromosomes were extracted using the Zymo DNA Extraction Kit. Detection of the chromate reductase gene in the bacterial genome DNA was carried out by PCR amplification method using a specific primer chromate reductase Gene $(C h R)$ Forward 5'TCACGCCGGAATATAACTAC- 'and Reverse 5'CGTACCCTGATCAATCACTT3'. The PCR program used for $C h R$ gene amplification was: initial denaturation at $94^{\circ} \mathrm{C}$ for 5 minutes, followed by 35 cycles of denaturation at $94^{\circ} \mathrm{C}$ for $30 \mathrm{~s}$, annealing at $50^{\circ} \mathrm{C}$ for $30 \mathrm{~s}$ and extension at $72^{\circ} \mathrm{C}$ for $1 \mathrm{~min}$ and a final extension at $72^{\circ} \mathrm{C}$ for $10 \mathrm{~min}$. The PCR product was qualitatively confirmed using DNA electrophoresis in $1.5 \%$ agarose gel and visualized using a UV transilluminator (EBOX VX2) (Patra et al. 2010).

\section{Identification of selected endophytic bacteria based on 16S rDNA}

DNA chromosome of the most potential endophytic bacteria was extracted using the Zymo DNA Extraction Kit. The sequence of $16 \mathrm{~S}$ rDNA was amplified using universal primers $27 \mathrm{f}$ ( 5 '-GAG AGT TTG CTG GCT ATC CAG- 3') and 1492r (5 '-CTA CGG CTA TGT CCT TAC
GA- 3 '). PCR amplification of 16S rDNA gene was carried out in PCR Mastercycler Personal (EPPENDORF) subjected to denaturation at $94^{\circ} \mathrm{C}$ for $5 \mathrm{~min}$, followed by 35 cycles consisting of denaturation at $94^{\circ} \mathrm{C}$ for $30 \mathrm{~s}$, annealing at $55^{\circ} \mathrm{C}$ for $30 \mathrm{~s}$ and extension at $72^{\circ} \mathrm{C}$ for 1,5 min and a final extension of $72^{\circ} \mathrm{C}$ for $10 \mathrm{~min}$. Amplicons of $16 \mathrm{~S}$ rDNA were purified and sequenced in First BASE, Malaysia. The 16S rDNA sequences of isolates were aligned with reference strains from BLAST and analyzed using the MEGA V.6 program. Phylogeny tree was constructed and inferred with the Neighbor-joining algorithm with the Tamura-Nei model using 1000 replicates bootstraps (Patra et al. 2010).

\section{RESULTS AND DISCUSSION}

\section{Isolation and screening of $\mathrm{Cr}$ (VI) tolerant endophytic bacteria from Ficus septica Burm.F}

The population density of endophytic bacteria on NA medium containing $150 \mathrm{mg} / \mathrm{L} \mathrm{Cr}$ (VI) was $2,23 \times 10^{5} \mathrm{CFU} / \mathrm{g}$ with population density in the control media (NA without $\mathrm{Cr}$ (VI)) was $9,68 \times 10^{5} \quad \mathrm{CFU} / \mathrm{g}$. A total of eight bacterial strains with different morphological colonies were isolated from endosphere of Ficus septica Burm.F All isolates were tolerant to $\mathrm{Cr}$ (VI) $500 \mathrm{mg} / \mathrm{L}$. In contrast, those tolerant to $\mathrm{Cr}$ (VI) $900 \mathrm{mg} / \mathrm{L}$ were only three isolates (E3, E4, and E8). Three other isolates could not grow at the highest concentration of $1000 \mathrm{mg} / \mathrm{L}$ (Table 1). Each bacterial isolate has a different tolerance level to $\mathrm{Cr}$ (VI).

The previous study by Khan et al. (2015) reported that endophytic bacteria isolated from Prosopis juliflora were tolerant of $\mathrm{Cr}$ (VI) up to $3000 \mathrm{mg} / \mathrm{L}$. Another study by Ramirez et al. (2019) showed that endophytic bacteria from Prosopis laevigata were tolerant of Cr (VI) $1474 \mathrm{mg} / \mathrm{L}$. Dimitroula et al. (2014) showed that endophytic bacteria from Juncus acutus were tolerant of Cr (VI) $100 \mathrm{mg} / \mathrm{L}$. Some mechanisms for $\mathrm{Cr}$ (VI) tolerance by bacteria were chromate regulator protein synthesis $(C h r A$ and $C h r B)$ by the chrBCAF operon which acts as a sensitive chromate regulator; balancing oxidative stress-induced $\mathrm{Cr}$ (VI) by activating ROS scavenging enzymes (e.g. catalase and superoxide dismutase), DNA repair with SOS response enzymes (RecA, RecA, RecG, RuvAB) to fight DNA damage and regulation of iron absorption to prevent the production of hydroxyl radicals through the Fenton reaction (Morais et al. 2011; Ahemad, 2014).

Table 1. Bacteria isolated from endosphere of Ficus septica Burm $\mathrm{F}$ that are tolerant of $\mathrm{Cr}(\mathrm{VI})$

\begin{tabular}{lcccccccccccc}
\hline \multirow{2}{*}{ Isolate } & \multicolumn{10}{c}{ Cr (VI) concentration (mg/L) } \\
\cline { 2 - 10 } & $\mathbf{1 5 0}$ & $\mathbf{2 0 0}$ & $\mathbf{3 0 0}$ & $\mathbf{4 0 0}$ & $\mathbf{5 0 0}$ & $\mathbf{6 0 0}$ & $\mathbf{7 0 0}$ & $\mathbf{8 0 0}$ & $\mathbf{9 0 0}$ & $\mathbf{1 0 0 0}$ \\
\hline E1 & + & + & + & + & + & - & - & - & - & - \\
E2 & + & + & + & + & + & + & - & - & - & - \\
E3 & + & + & + & + & + & + & + & + & + & - \\
E4 & + & + & + & + & + & + & + & + & + & - \\
E5 & + & + & + & + & + & - & - & - & - & - \\
E6 & + & + & + & + & + & - & - & - & - & - \\
E7 & + & + & + & + & + & + & + & - & - & - \\
E8 & + & + & + & + & + & + & + & + & + & - \\
\hline
\end{tabular}

Note: + (growth), -(no growth) 


\section{The potency of endophytic bacteria to produce IAA}

Three endophytic bacteria (E3, E4, and E8) produced a pink color on the nitrocellulose membrane indicated IAA production. The high concentrations of IAA produce a deep pink color, and the lower concentrations yield a light pink color after exposure to the Salkowski reagent (Figure 1a).

Pink color intensity indicates indole formation from the IAA complex and the reduction of $\mathrm{Fe}^{3+}$. The difference in the intensity of the pink color is caused by the presence of various indole compounds as products of tryptophan metabolism, such as indolpirufic acid and indoleacetamide (Bric et al., 1991). Singh et al. (2014) reported that red or pink color was an indication of indole detection in IAA. Quantitative data on IAA production corresponding with qualitative determination showing that all three isolates (E3, E4, and E8) have varying abilities in producing IAA (Figure 1b). The three isolates produce an optimal IAA hormone at 48 hours of incubation. E8 isolate produced the highest IAA $(20.05 \mu \mathrm{g} / \mathrm{mL})(\mathrm{p}<0.05)$. All isolates showed decreased IAA concentrations at 72 hours of incubation. The optimum IAA production was in the final logarithmic growth phase goes to the stationary phase. A decrease in IAA production in E8 isolates was after 72 and 48 hours of incubation indicates a phase of death.

According to Lugtenberg and Kamilova (2009), at the beginning of the stationary phase, microbial growth is constant. The number of nutrients in the medium decreases and the product of secondary metabolites were generally increased. Nutrients in the medium are used to maintain the number of living cells available. In the microbial death phase, the microbes die due to the reduced amounts of nutrients and increased toxic metabolites in the medium so that the number of biomass decreases. A decrease in IAA concentration after the initial stationary phase indicates a reduction of nutrients in the medium, so bacteria utilize IAA as a source of nutrition. Donoso et al. (2017) reported that bacteria used IAA as a carbon and energy source employing the iac gene under controlled of tautomerase superfamilies. Iac gene regulation is also regulated by the response of the MarR-type transcriptional repressor.

Javaid and Sultan (2012) reported that Streptomyces matansis was able to produce $16 \mu \mathrm{g} / \mathrm{mL}$ IAA in media containing $50 \mathrm{mg} / \mathrm{L} \mathrm{Cr}$ (VI). Oves et al. (2013) showed that Pseudomonas aeruginosa OSG41 isolate was able to produce $24.2 \mu \mathrm{g} / \mathrm{mL}$ IAA in the media containing Cr (VI) $200 \mathrm{mg} / \mathrm{L}$ and L-Tryptophan $1 \%$. The ability of endophytic bacteria Pseudomonas aeruginosa OSG41 to produce IAA is almost the same as E8 isolates. In this study, IAA was detected early because this hormone is the main parameter that increases the adaptation and tolerance of plants which are gripped by heavy metals by inducing physiological changes (Liphadzi et al., 2006). Tandon et al. (2015) show that exogenous IAA increases phytoremediation efficiency in wastewater treatment. The difference in IAA production potential is due to differences in isolates, L-Tryptophan and $\mathrm{Cr}$ (VI) concentrations contained in the medium.
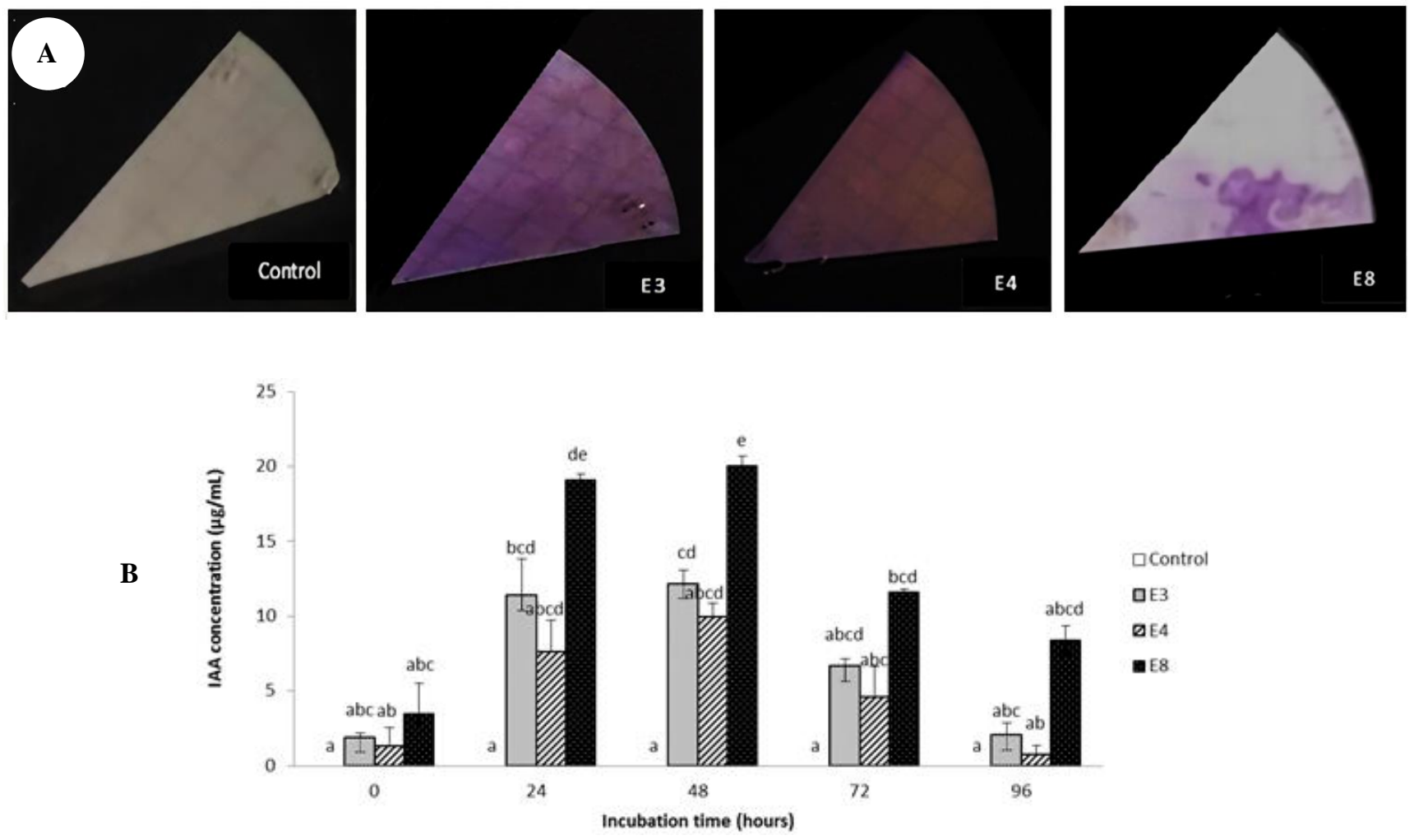

Figure 1.A. Pink color formation by bacteria after reacting with Salkowski"s reagents on the nitrocellulose membrane indicated the production of IAA. B. The concentration of IAA production by endophytic bacteria. Data were expressed as the mean \pm standard deviation of three replicates using Two-way ANOVA test at $\mathrm{a}=0.05$. Different notations indicate significant difference among treatments $(\mathrm{p}<0.05)$. 
Table 2. Solubilization index (SI) and EPS production of three endophytic bacterial isolates at two different carbon sources

\begin{tabular}{|c|c|c|c|c|}
\hline \multirow[b]{2}{*}{ Isolate } & \multirow[b]{2}{*}{ SI* } & \multicolumn{3}{|c|}{ EPS } \\
\hline & & Glucose & Sucrose & $\begin{array}{l}\text { Total EPS } \\
(\mu \mathrm{g} / \mathrm{mL}) *\end{array}$ \\
\hline Control & $1 \pm 0^{\mathrm{a}}$ & - & - & $0^{\mathrm{a}}$ \\
\hline E3 & $1.54 \pm 0.05^{\mathrm{c}}$ & - & + & $7.66 \pm 0.09^{c}$ \\
\hline E4 & $1.32 \pm 0.05^{\mathrm{b}}$ & + & + & $5.70 \pm 0.09^{b}$ \\
\hline E8 & $1.52 \pm 0.07^{\mathrm{c}}$ & + & + & $9.70 \pm 0.01^{\mathrm{d}}$ \\
\hline
\end{tabular}

Note: *Data were expressed as mean \pm standard deviation, notation differences show significant differences in the Anova test $(\alpha=0.05) ;+$ (slime formed), - (not slime formed)

\section{The potency of endophytic bacteria in phosphate solubilizing and EPS production}

Qualitative results showed that the three isolates were able to dissolve phosphate that indicated by the formation of halo zones around the disk paper and the Solubilization index (SI). The highest SI was performed by isolate E3 (1.54) which was not significantly different $(p>0.05)$ from isolate E8 (Table 2).

Formation of halo zones indicates the capability of bacteria to dissolve tricalcium phosphate $(\mathrm{Ca} 3(\mathrm{PO} 4) 3 \mathrm{OH})$ in the media as a source of phosphate in the presence of phosphatase enzyme (acid phosphatase (AcPase)) (Thakuria et al., 2004) The results of the qualitative determination are corresponding with the quantitative determination. E8 isolate was able to dissolve the highest phosphate $(129.33 \mu \mathrm{g} / \mathrm{mL})$ and the fastest at 48 hours of incubation time. The concentration of dissolved phosphate decreased significantly at 72 hours of incubation time. E3 isolate was able to dissolve phosphate of $127.78 \mu \mathrm{g} / \mathrm{mL}$ at 72 hours of incubation that was not significantly different (p>0.05) from E8 isolate at 48 hours of incubation (Figure $2)$. The optimum condition for phosphate solubilization indicates that the bacterium is in the final logarithmic growth phase towards stationary. The decrease in dissolved phosphate concentration indicates bacterial isolates in the stationary phase leading to death. Bacteria $P$. aeruginosa OSG41 can dissolve phosphate to a concentration of 185.6 $\mu \mathrm{g} / \mathrm{mL}$ on media containing $200 \mathrm{mg} / \mathrm{L} \mathrm{Cr}$ (VI) (Oves et al. 2013).

The qualitative determination of EPS production showed variations of EPS production due to differences in carbon sources in NA medium. EPS production in bacterial isolates is characterized by thick slime and the formation of mucus in the colony. E3 isolate showed the accumulation of mucus in glucose-containing medium, while isolates E4 and E8 both using glucose and sucrose as carbon sources that indicated by the mucous formation in NA media containing glucose and sucrose (Table 2). Pawar et al. (2013) reported that in the media containing sucrose as carbon source produces higher total EPS than that of glucose as a carbon source at the same concentration. It shows that sucrose can be more metabolized than glucose, so in quantitative determination, the carbon source used is sucrose.

Quantitative determination showed that endophytic bacteria; E8 produced the highest total of EPS (9.70 $\mu \mathrm{g} / \mathrm{mL})(\mathrm{p}<0.05)$ whereas E3 and E4 produce EPS 7.66 $\mu \mathrm{g} / \mathrm{mL}$ and $5.70 \mu \mathrm{g} / \mathrm{mL}$, respectively (Figure 3). Rida et al. (2015) reported that Pseudomonas aeruginosa $\mathrm{Rb}-1$ and Ochrobactrum intermediate $\mathrm{Rb}-2$ grown on medium containing $\mathrm{Cr}$ (VI) $1000 \mathrm{mg} / \mathrm{L}$ produce total EPS 4.15 $\mu \mathrm{g} / \mathrm{mL}$ and $13.63 \mu \mathrm{g} / \mathrm{mL}$, respectively. Harish et al. (2012) showed that Enterobacter cloacae produced EPS $78 \mu \mathrm{g} / \mathrm{mL}$ in a medium containing $\mathrm{Cr}$ (VI) $100 \mathrm{mg} / \mathrm{L}$.

Differences in the ability to dissolve phosphate and EPS production is due to differences in the species of bacteria and the concentration of $\mathrm{Cr}$ (VI) in the medium. IAA production and phosphate solubility decrease while EPS production increases with increasing concentration of $\mathrm{Cr}$ (VI) at a particular concentration (Dogan et al. 201; Oves et al. 2013).

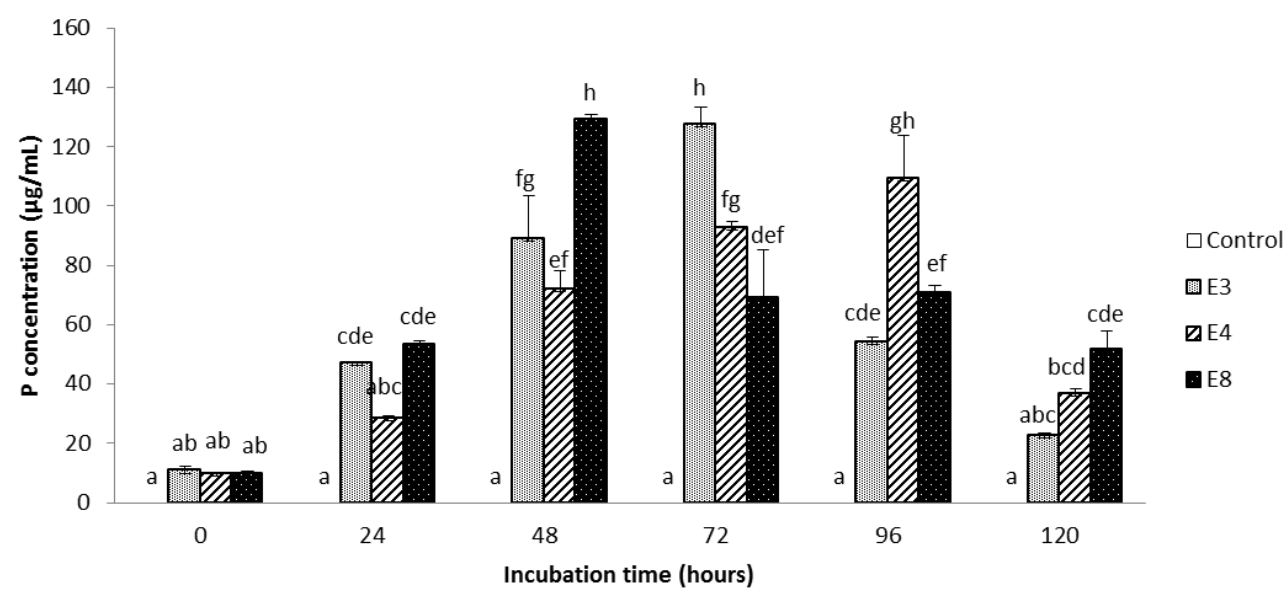

Figure 2. Phosphate solubilizing ability of endophytic bacteria. Data were expressed as the mean \pm standard deviation of three replicates using Two-way ANOVA test at $\mathrm{a}=0.05$. Different notations indicate significant difference among treatments $(\mathrm{p}<0.05)$. 


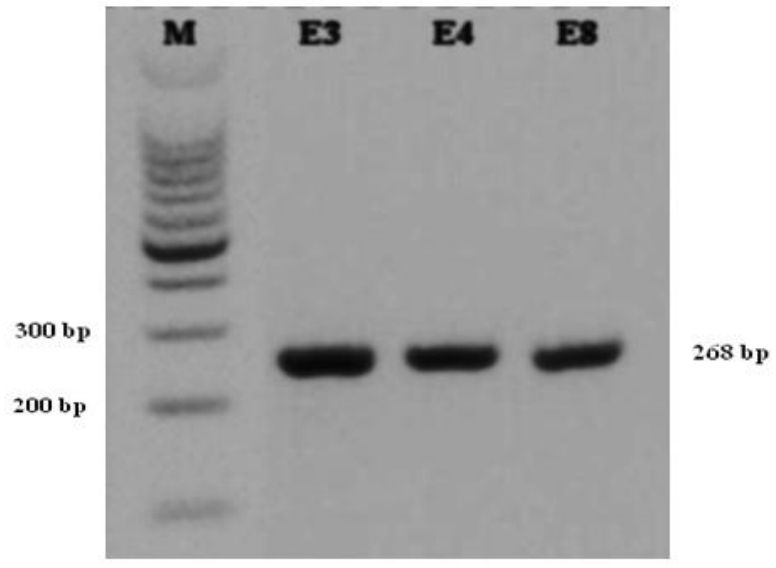

Figure 4. Results of $C h R$ gene fragment amplification

\section{The chromate reductase $(\mathrm{ChR})$ gene in Endophytic bacteria}

Three endophytic bacteria (E3, E4, and E8) were tolerant of $\mathrm{Cr}$ (VI) were analyzed for their $C h R$ gene. The results showed that these isolates had a $C h R$ gene of $268 \mathrm{bp}$ when confirmed using DNA ladder (Figure 4). Similar results were reported by Patra et al. (2010) that the $C h R$ gene in Arthrobacter aurescens, Bacillus atrophaeus, and Rhodococcus erythropolis was 268 bp. Research by Sanjay et al. (2018) showed that Klebsiella pneumoniae and Mangrovibacter yixingensis also had a ChR gene of $268 \mathrm{bp}$. The $C h R$ gene encodes an enzyme that catalyzes the reduction reaction of $\mathrm{Cr}$ (VI) to $\mathrm{Cr}$ (III) (Wani and Adeosun 2017).

Wang et al. (1990) reported that Escherichia coli ATCC 33456, Orchobactrum anthtopi, and Enterobacter cloacae $\mathrm{HO} 1$ possess the $C h R$ gene. These bacteria can reduce $\mathrm{Cr}$ (VI) aerobically by involving $\mathrm{NAD}(\mathrm{P}) \mathrm{H}$ extracellular reductase. These bacteria are also able to reduce $\mathrm{Cr}$ (VI) to $\mathrm{Cr}$ (III) anaerobically by involving amino acids, nucleotides, carbohydrates, vitamins and organic acids as electron donors and $\mathrm{Cr}$ (VI) as the terminal electron. The reduction mechanism of $\mathrm{Cr}$ (VI) associated with cell membranes requires $\mathrm{H}_{2}$ or glucose as electron donors (Cheung and $\mathrm{Gu}$ 2007).

\section{Potential endophytic bacterial species as $\mathrm{Cr}$ (VI) phytoremediation promoting agent}

Phylogeny tree of the most potential endophytic bacteria was constructed based on the similarity of $16 \mathrm{~S}$ rDNA sequences The result of Figure 5 showed that E8 isolate was found to be $100 \%$ identical to Enterobacter cloacae. Chitraprabha and Sathyavathi (2018) reported that Enterobacter cloacae associated with Tagetes erecta could accumulate and reduce $\mathrm{Cr}$ (VI). Kumar et al. (2014) identified Enterobacter aerogenes that resistant to $\mathrm{Cr}$ (VI) up to $600 \mathrm{mg} / \mathrm{L}$ and was able to produce IAA and solubilize phosphate. Khan et al. (2015) identified Enterobacter sp. That is tolerant to $\mathrm{Cr}$ (VI) and capable of producing phytoremediation supporting compounds.

Three endophytic bacteria isolates (E3, E4, and E8) were tolerant of $\mathrm{Cr}(\mathrm{VI})$ up to $900 \mathrm{mg} / \mathrm{L}$ and able to produce IAA, dissolve phosphate, and produce EPS. The three isolates have the potential to support Ficus septica Burm.F in remediating the polluted ecosystem of $\mathrm{Cr}(\mathrm{VI})$, with $\mathrm{E} 8$ as the highest potential isolate. IAA produced by bacteria plays an important role in increasing plant IAA and metal detoxification. IAA stimulates the production of root exudates, the proliferation of lateral and adventitious roots, and induces the synthesis of ACC synthase. It supports the absorption of nutrients and metals and increases plant adaptation and tolerance to heavy metals (Liphadzi et al. 2006).

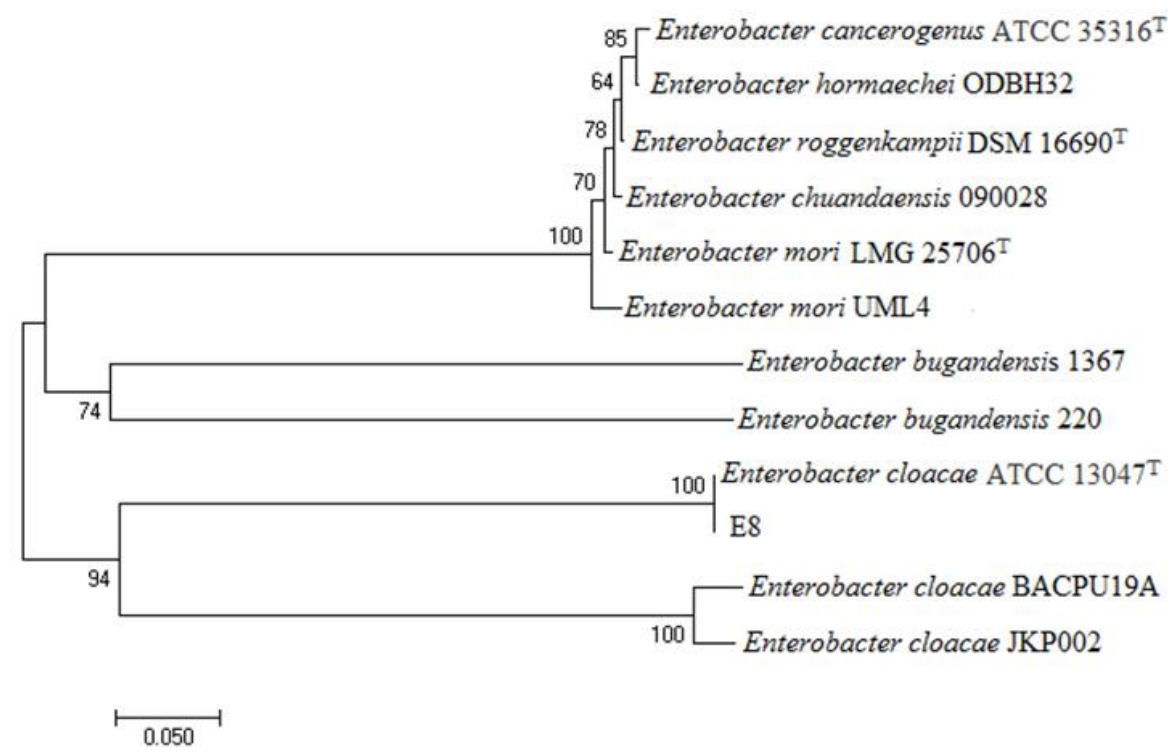

Figure 5. Phylogenic trees of E8 isolates and reference isolates based on the similarity of 16S rDNA sequences with Neighbor-Joining algorithm 
The ability of bacteria to dissolve phosphate can increase bioavailability and absorption of metals and nutrients in the soil by plants. Phosphate solubilizing bacteria can also release bonds of precipitated metal sulfides so that they accumulate for plant growth (Sharma et al. 2013). Exopolysaccharides act as barriers layer to heavy metals through biosorption which includes the exchange of metal ions, complexation with negative charges of functional groups, adsorption, and precipitation. Besides, EPS also acts as a protection against pathogens, phagocytosis, and infections by bacteriophages. Endophytic bacteria can support the phytoremediation of $\mathrm{Cr}$ (VI) due to the presence of a $C h R$ gene that can reduce the toxic $\mathrm{Cr}$ (VI) to the less toxic $\mathrm{Cr}$ (III) (Oves et al. 2013). This result was confirmed by Rosariastuti et al. (2013) which shows that the Agrobacterium rhizogenes bacterium can accumulate and reduce the heavy metal $\mathrm{Cr}$ (VI) in the shoots and stimulate plant growth

The $\mathrm{Cr}$ (VI) tolerant endophytic bacteria associated with Ficus septica Burm.F were potential to protects the plant against the inhibitory effects of $\mathrm{Cr}(\mathrm{VI})$, reduced heavy metals toxicity, and leading to enhanced remediation of contaminated soil and water and environmentally and economically sustainable plant biomass production.

\section{ACKNOWLEDGEMENTS}

The authors would like to gratefully thank all the members of Microbiology Working Group of Biology Department, Brawijaya University, Malang, Indonesia for giving valuable suggestions, comments, and help to carry out this research.

\section{REFERENCES}

Ahemad M. 2014. Bacterial mechanisms for $\mathrm{Cr}(\mathrm{VI})$ resistance and reduction: an overview and recent advances. Folia Microbiol. DOI 10.1007/s12223-014-0304-8

Bric JM, Bostock RM, Silverstone SE. 1991. Rapid in situ assay for Indole Acetic Acid production by bacteria immobilized on a nitrocellulose membrane. Applied and Environmental Microbiology 57: 535-538.

Camargo FAO, Bento FM, Okeke BC. Frankenberger WT. 2003 Chromate reduction by chromium resistant bacteria isolated from soils contaminated with dichromate. J Environ Qual 32: 1228-1233.

Cervantes C, Campos-Garcia J, Devars S, Gutierrez-Corona F, LozaTavera H, Torres-Guzman JC, Moreno-Sánchez R. 2001. Interactions of chromium with microorganisms and plants. FEMS Microbiol Rev 25: 335-347.

Cervantes CH, Ohtake L. Chu TK, Misra S, Silver. 1990. Cloning nucleotide sequence and expression of the chromate resistance determinants of Pseudomonas aeruginosa plasmid pUM505. J Bacteriol 172: 287-291.

Ce'rantola S, Boune'ry JD, Segonds, C, Marty N. 2000. Exopolysaccharide production by mucoid and nonmucoid strains of Burkholderia cepacia. FEMS Microbiol 185: 243-246.

Cheung KH, Gu JD. 2007. Mechanism of hexavalent chromium detoxification by microorganisms and bioremediation application potential: a review. Intl Biodeterior Biodegrad 59: 8-15.

Chitraprabha KS, Sathyavathi. 2018. Phytoextraction of chromium from electroplating effluent by Tagetes erecta (L.). Sustain Environ Res. 28: $128-134$.
Davies KL, Davies MS, Francis D. 2001. Zinc-induced vacuolation in root meristematic cells of Festuca rubra L. Plant Cell Environ 14: 399. 406.

Dimitroula H, Evdokia S, Eleni M, Nikolaos PN. Karatzas, Nicolas K. 2014. Mitigation measures for Chromium-VI contaminated groundwater-the role of endophytic bacteria in rhizofiltration. J Hazard Mater. DOI: 10.1016/j.jhazmat.2014.08.005

Dogan NM, Kantar VS, Gulcan CJ, Dodge BC, Yilmaz, Mazmanci MA. 2011. Chromium(VI) bioremoval by Pseudomonas Bacteria: Role of microbial exudates for natural attenuation and biotreatment of $\mathrm{Cr}(\mathrm{VI})$ contamination. Environ Sci Technol 45: 2278-2285.

Donoso R, Leiva-Novoa P, Zúñiga A, Timmermann T, Recabarren G, González B. 2017. Biochemical and genetic bases of indole-3-acetic acid (auxin phytohormone) degradation by the plant-growthpromoting rhizobacterium Parabulkholderia phytofirmans PsJN. App Environ Microbiol. 83: 1-16.

Glickmann E, Dessaux Y. 1995. A critical examination of the specificity of the Salkowski reagent for indolic compounds produced by phytopathogenic bacteria. App Environ Microbiol 61: 793-796.

Harish R, Jastin S, Mishra R, Chandrasekaran N, Mukherjee A. 2012. Bioreduction of $\mathrm{Cr}(\mathrm{VI})$ by exopolysaccharides (EPS) from indigenous bacterial species of Sukinda chromite mine, India. Biodegradation 23: 487-496.

Harley JP, Prescott LM. 2002. Laboratory Exercises in Microbiology. 5th ed. McGraw-Hill, New York.

Hynninen A, Virta M. 2009 Whole-cell bioreporters for the detection of bioavailable metals. Adv Biochem Eng Biotechnol. DOI: 10.1007/10_2009_9

Javaid M, Sikander S. 2012. Plant growth promotion traits and Cr (VI) reduction potentials of $\mathrm{Cr}$ (VI) resistant Streptomyces strains. J Basic Microbiol 52: 1-10.

Khan MU, Angela S, Muhammad H, Kaneez F, Asma I, Muhammad A, Ghulam S, Qaiser MK, Muhammad A. 2015. Cr-resistant rhizo- and endophytic bacteria associated with Prosopis juliflora and their potential as phytoremediation enhancing agents in metal-degraded soils. Front Plant Sci 5: 755. DOI: 10.3389/fpls.2014.00755

Krishna KR, Philip L. 2005. Bioremediation of $\mathrm{Cr}(\mathrm{VI})$ in contaminated soils. J Hazard Mater 121: 109-117.

Kumar VR, Kothari SK, Tyagi. 2014. Biological hydrogen production by facultative anaerobic bacteria Enterobacter aerogens (MTCC 8100). Recent Adv Bioenergy Res 3: 25.

Laghlimi M, Baghdad B, El Hadi H, Bouabdli A. 2015. Phytoremediation mechanisms of heavy metal contaminated soils: A review. Open J Ecol 5: 375-388.

Liphadzi MS. Kirkham MB, Paulsen GM.. 2006. Auxin-Enhanced Root Growth for Phytoremediation of Sewage-Sludge Amended Soil. Environ Technol 27: 695-704.

Lugtenberg B, Kamilova F. 2009. Plant-growth-promoting rhizobacteria. Annu Rev Microbiol 63: 541-556.

Luo J, Cai L, Qi S, Wu J, Gu XS. 2018. Heavy metal remediation with Ficus microcarpa through transplantation and its environmental risks through field scale experiment. Chemosphere 193: 244-250.

Malik A. 2004. Metal bioremediation by growing cells. Environ Intl 30: 261-278.

Morais PV, Branco R, Francisco R. 2011. Chromium resistance strategies and toxicity: what makes Ochrobactrum tritici 5 bvl1 a strain highly resistant. Biometals 24: 401-410.

Oves M, Saghir KM, Zaidi A. 2013. Chromium reducing and plant growth-promoting novel strain Pseudomonas aeruginosa OSG41 enhance chickpea growth in chromium amended soils. Eur J Soil Biol. 56: 72-8.

Patra RC, Malik S, Beer M, Megharaj M, Naidu R. 2010 Molecular characterization of chromium (VI) reducing potential in Grampositive bacteria isolated from contaminated sites. Soil Biol Biochem 42: $1857-1863$

Pawar ST, Bhosale AA, Gawade TB, Nale TR. 2013. Isolation, screening, and optimization of exopolysaccharide producing-bacterium from the saline soil. J Microbiol Biotechnol 3: 24-31.

Premono ME, Moawad AM, Vlek PLG. 1996. Effect of phosphatesolubilizing Pseudomonas putida on the growth of maize and its survival in the rhizosphere. Indonesian J Crop Science 11: 13-12.

Rida B, Kim Y, Kamran S, Nazia J, Shahida H. 2015. Production of EPS under $\mathrm{Cr}(\mathrm{VI})$ challenge in two indigenous bacteria isolated from a tannery effluent J Basic Microbiol 54: 1-11. 
Ramírez V, Antonino B, Primavera L, Rocío B, Miguel ÁV, Ricardo C, José LC, Jesús M, Luis EF, Javier M, José AM. 2019. Chromium hyper-tolerant Bacillus sp. MH778713 assists phytoremediation of heavy metals by mesquite trees (Prosopis laevigata). Front Microbiol. DOI: $10.3389 /$ fmicb.2019.01833

Rosariastuti R, Prijambada ID, Ngadiman PGS, Putri AR. 2013. Isolation and identification of plant growth promoting and chromium uptake enhancing bacteria from soil contaminated by leather tanning industrial waste. J Basic Appl Sci 9: 243-251.

Sanjay MS, Dorairaj S, Gnanaprakasam AR, Kathirvelu B. 2018. Isolation and identification of chromium reducing bacteria from tannery effluent. J King Saud Univ Sci 32 (1): 265-271. DOI 10.1016/j.jksus.2018.05.001

Schiavon M, Pilon-Smits MWR, Hell, Malagoli M. 2008. Interactions between chromium and sulfur metabolism in Brassica juncea. J Environ Quality 37: 1536-1545.

Sharma SBRZ, Sayyed MH, Trivedi TA, Gobi. 2013. Phosphate solubilising microbes: sustainable approach for managing phosphorus deficiency in agricultural soils. Springerplus 2: 587. DOI: 10.1186/2193-1801-2-587.

Singh J, Carlisle DL, Pritchard DE, Patierno SR. 1998. Chromiuminduced genotoxicity and apoptosis: relationship to chromium carcinogenesis (review). Oncology Rep 5: 1307-1318.

Singh P, Kumar V, Agrawal S. 2014. Evaluation of phytase producing bacteria for their plant growth-promoting activities. Intl J Microbiol 2020: 426483. DOI: $10.1155 / 2014 / 426483$.
Srivastava VC, Mall ID, Mishra IM. 2006. Modelling individual and competitive adsorption of Cadmium (II) and Zinc(II) metal ions from aqueous solution onto bagasse fly ash. Sep Sci Technol 41: 26852710

Tallgren AH, Airaksinen U, von Weissenberg R, Ojamo H J, Kuusisto, Leisola M. 1999. Exopolysaccharide-producing bacteria from sugar beets. J Appl Environ Microbiol 65: 862-864.

Tandon SA, Kumar R, Parsana S. 2015. Auxin treatment of wetland and non-wetland plant species to enhance the phytoremediation efficiency to treat municipal wastewater. J Sci Res 74: 702-707.

Thakuria D, Talukdar NC, Goswami C, Hazarika S, Boro RC, Khan MR. 2004. Characterization and screening of bacteria from rhizosphere of rice grown in acidic soils of Assam. Curr Sci 7: 978-985.

Tirry NN, Tahri Joutey H, Sayel A, Kouchou W, Bahafid M, Asri N, El G. 2018. Screening of plant growth-promoting traits in heavy metals resistant bacteria: Prospects in phytoremediation. J Genet Eng Biotechnol 16: 613-619.

Wani PA, Adeosun BO. 2017. Cr (VI) removal by indigenous Klebsiella species PB6 isolated from contaminated soil under the influence of various factors. Curr Res Bacteriol 8: 62-69.

Wang PC, Mori T, Toda K, Ohtake H. 1990. Membrane-associated chromate reductase activity from Enterobacter cloacae. J Bacteriol 172: 1670-1672.

Yeo CK, Tan HTWW. 2011. Ficus stranglers and melastoma malabathricum: potential tropical woody plants for phytoremediation of metals in wetlands. Nat Sing 4: 213-226. 